\title{
Pathological findings and survey for pathogens associated with reproductive failure in perinatal Steller sea lions Eumetopias jubatus
}

\author{
J. A. Esquible ${ }^{1}$, K. Burek-Huntington ${ }^{2}$, S. Atkinson ${ }^{3, *}$, A. C. Klink ${ }^{4}$, E. Bortz ${ }^{4}$,

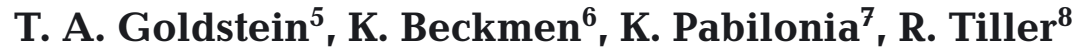 \\ ${ }^{1}$ College of Fisheries and Ocean Sciences, University of Alaska Fairbanks, 107 Alex Hately, Bethel, AK 99559, USA \\ ${ }^{2}$ Alaska Veterinary Pathology Services, 23834 The Clearing Dr, Eagle River, AK 99577, USA \\ ${ }^{3}$ College of Fisheries and Ocean Sciences, University of Alaska Fairbanks, 17101 Pt. Lena Loop, Juneau, AK 99801, USA \\ ${ }^{4}$ Department of Biological Sciences, University of Alaska Anchorage, 3211 Providence Drive, Anchorage, AK 99508, USA \\ ${ }^{5}$ Karen C. Drayer Wildlife Health Center, University of California Davis, School of Veterinary Medicine, Davis, CA 95616, USA \\ ${ }^{6}$ Alaska Department of Fish \& Game, Division of Wildlife Conservation, 1300 College Road, Fairbanks, AK 99701, USA \\ ${ }^{7}$ College of Veterinary Medicine and Biomedical Sciences, Colorado State University, 2450 Gillette Drive, Fort Collins, \\ CO 80523, USA \\ ${ }^{8}$ Centers for Disease Control and Prevention, 1600 Clifton Rd NE, Atlanta, GA 30333, USA
}

\begin{abstract}
Steller sea lions (SSLs) Eumetopias jubatus experienced a population decline in the 1960 s, leading to the listing of the western stock as endangered and the eastern stock as threatened under the US Endangered Species Act. A decrease of births in the western stock beginning in the late 1960s indicates that reproductive failure may have contributed to the decline. We evaluated the role pathogens play in spontaneous abortions, premature births and neonatal deaths in SSLs. Archived tissues from carcasses $(n=19)$ collected in Alaska from 2002 to 2015 were tested by PCR for Coxiella burnetii, Brucella spp., Chlamydia and morbilliviruses. Animals examined included $47 \%$ premature pups, $32 \%$ aborted fetuses, $11 \%$ neonates and $11 \%$ intrauterine fetuses. Gross necropsy and histology findings were summarized in the context of the PCR findings. Tissues were negative for Chlamydia and $C$. burnetii. Brucella spp. were detected in the lung tissues of 3 animals, including 1 positive for the ST27 strain, the first detection of Brucella spp. DNA in SSLs. Phocine distemper virus was detected in 3 animals in 2 skin lesions and 1 placenta by heminested diagnostic qRT-PCR. Both skin and the placental lesions had vesiculoulcerative changes, and 1 skin lesion contained inclusion bodies in syncytia and upon histologic examination, suggesting that the lesions may be associated with an infection reminiscent of phocine distemper virus, the first in SSLs. We highlight the continuing need for disease surveillance programs to improve our understanding of the prevalence and potential population impacts of these infectious disease agents for pinnipeds in Alaskan waters.
\end{abstract}

KEY WORDS: Eumetopias jubatus - Steller sea lion · Reproductive failure · Brucella spp. · Morbillivirus $\cdot$ Coxiella burnetii $\cdot$ Chlamydia $\cdot$ Alaska

\section{INTRODUCTION}

The Steller sea lion (SSL) Eumetopias jubatus has been intensively studied as a result of the major decline in abundance beginning in the 1960s, which led

\footnotetext{
${ }^{*}$ Corresponding author: skatkinson@alaska.edu
}

to the listing of the western SSL stock as endangered, and the eastern SSL stock as threatened under the US Endangered Species Act (Loughlin \& York 2000, Ferrero \& Fritz 2002, Miller et al. 2005, Atkinson et al. 2008). The eastern stock was delisted in 2014; how-

() The authors 2019. Open Access under Creative Commons by Attribution Licence. Use, distribution and reproduction are unrestricted. Authors and original publication must be credited. 
ever, scientists continue to investigate the factors and potential causes of differences in regional trends (Fritz et al. 2013). Disease, malnutrition, predation, climate change, decreased birth rate, entanglement in marine debris and other factors may have led to the decline (Loughlin 1998, Pitcher et al. 1998, Trites \& Donnelly 2003, Burek et al. 2005, Atkinson et al. 2008). A decline in estimated parturition rates for adult females in the western stock from the 1970s to the mid-1980s suggests that reproductive failure may have contributed to a decline in abundance (Pitcher \& Calkins 1981, Calkins \& Goodwin 1988). Agestructured modeling by Holmes et al. (2007) suggests that the parturition rates in the central Gulf of Alaska continued to decline through 2004, and declining parturition rates may be problematic for the recovering western SSL stock. Furthermore, poorly documented accounts of dead pups at some locations suggest that perinatal mortality may have occurred. Females give birth between mid-May and mid-June, breed about $10 \mathrm{~d}$ afterwards (Pitcher et al. 1998), and exhibit embryonic diapause and delayed implantation after 3 mo (Pitcher \& Calkins 1981). Winship et al. (2001) suggest that there is very little fetal growth occurring prior to February. Gestation lasts for 11.5 mo (Pitcher \& Calkins 1981), and Pitcher et al. (1998) have documented spontaneous abortions during the last 4.5 mo of gestation.

Coxiella burnetti is a zoonotic bacteria associated with reproductive failure in a disease named ' $Q$ fever'. Large numbers of $C$. burnetti organisms in the placenta can be transmitted to the pup during parturition (Maurin \& Raoult 1999). Clinical signs include abortion, premature birth, and dead or weak offspring in multiple taxa, particularly sheep, goats and cattle (Arricau-Bouvery \& Rodolakis 2005). C. burnetii placentitis was reported in an ill, pregnant Pacific harbor seal Phoca vitulina richardsi in northern California in 1998 (Lapointe et al. 1999) and in the placenta of a dead pregnant SSL stranded off Washington in 2008 (Kersh et al. 2010). Molecular and serological studies show that SSLs in the western stock and northern fur seals Callorhinus ursinus in Alaska have been exposed to infection by C. burnetii (e.g. Minor et al. 2013), but it is unclear whether this pathogen causes disease in northern fur seals.

Brucella spp. are widespread zoonotic bacteria (Nymo et al. 2011, Guzmán-Verri et al. 2012, Hernández-Mora et al. 2013) known to cause abortion in wildlife, domestic animals (Ewalt et al. 1994) and humans. Brucella spp. have also been found in a variety of marine mammals, with an unclear role in reproductive failure or association with disease (Fos- ter et al. 2002, Nymo et al. 2011). It was first detected in 1994 in a stranded harbor seal, a harbor porpoise Phocoena phocoena, a common dolphin Delphinus delphis and an aborted bottlenose dolphin Tursiops truncatus fetus (Nymo et al. 2011). Since then, marine Brucella have been divided into 2 species, B. pinnipedialis and $B$. ceti, which primarily but not exclusively occur in pinnipeds and cetaceans, respectively, and have been detected throughout the world. Pathology associated with marine Brucella has been seen exclusively in cetaceans and includes blubber abscesses, subcutaneous lesions, skin lesions, meningoencephalitis, discospondylitis, as well as reproductive pathology including aborted fetuses, mastitis, placentitis and endometritis. However, isolates have also been obtained from multiple tissues including reproductive tissues in cetaceans and pinnipeds, with no associated pathology.

In pinnipeds, exposure to and detection of Brucella is quite common in true seals; however, pathology consistent with Brucella infection is near absent and vertical transmission of this species of Brucella ( $B$. pinnipedialis) has not been observed (Nymo et al. 2011). In one study in harbor seals, Brucella was detected in lung lesions; however, these animals also demonstrated lungworm infections, and lungworms are thought to play a possible role in Brucella transmission (Lambourn et al. 2013). In contrast, placentitis and multifocal acute necrosis associated with Brucella has been reported in a limited number of eared seal species including California sea lions Zalophus californianus and northern fur seals, indicating that transplacental transmission occurs and that morbidity and mortality may be associated with Brucella infection in eared seals (Goldstein et al. 2009b, Duncan et al. 2014).

For zoonotic potential, there have only been 3 reported cases of natural human infection associated with marine Brucella sp., and all were associated with Brucella sequence type (ST) 27 (Whatmore et al. 2008). In these human cases, no direct contact with marine mammals was reported, and there is some suggestion that there may be a lower trophic level host such as shellfish or fish for this strain (Whatmore et al. 2008, 2017). This strain appears to be relatively rare in the marine mammal cases, as this was reported with one aborted bottlenose dolphin fetus off the western coast of the USA (Whatmore et al. 2008), and, more recently, was found in 3 more bottlenose dolphins and in 4 cases in California sea lions (Goldstein et al. 2009b, Whatmore et al. 2017).

In Alaska, Burek et al. (2005) found one SSL seropositive for antibodies to B. abortus, and Nymo et 
al. (2018) detected Brucella antibodies in 2 SSLs. True seals, including harbor seals, had substantial portions of the population that were serologically positive (Hoover-Miller et al. 2017, Nymo et al. 2018). The reason for the much lower seropositive rate in SSLs versus true seals could be lack of exposure, increased resistance, or, considering pathology seen in other eared seals, potentially the loss of positive individuals from the population due to morbidity or mortality (Nymo et al. 2018). This increases the significance in determining the role of Brucella in SSL abortion cases. Researchers have yet to isolate the zoonotic ST27 strain in Alaskan waters, which is of great concern considering the public health implications this could have in coastal Alaskan communities.

Chlamydiae comprise some of the oldest and most successful groups of intracellular organisms and cause a wide variety of disease in animals and people. Despite ongoing controversy about the 2 genera of Chlamydiae (Chlamydia and Chlamydophila), since 2015, it has been accepted to combine the 2 into a single genus, Chlamydia; therefore, we will refer to all organisms in this group as Chlamydia spp. in this publication, consistent with current nomenclature (Sachse et al. 2015). Species of known pathogenic Chlamydia and associated hosts include $C$. abortus (sheep and goats), C. avium (pigeon and parrots), C. caviae (guinea pigs), C. felis (cats), C. gallinacean (chickens), C. muridarum (rodents and chickens), C. pecorum (cattle, koalas), C. pneumoniae (humans, horses and koalas), C. psittaci (birds), C. suis (swine) and C. trachomatis (humans) (Kauffold et al. 2014, Sachse et al. 2015). Members of the Chlamydiae cause reproductive abortions, respiratory disease and cardiovascular disease in a wide range of species (Beeckman \& Vanrompay 2009). C. abortus, previously categorized as C. psittaci, causes ovine enzootic abortion in sheep and reproductive failure in other large ruminants (Rodolakis et al. 1998, Longbottom \& Coulter 2003, Vidal et al. 2017). Routes of transmission vary and include horizontal transmission via ingestion, inhalation or venereal transmission (Van Loock et al. 2003, Kauffold et al. 2014). C. psittaci infections are common in birds, affecting at least 465 species, and generally result in respiratory disease (Kaleta \& Taday 2003). Serological studies report C. psittaci antibodies in SSLs (Burek et al. 2005), Hawaiian monk seals Monachus schauinslandi (Aguirre et al. 2007) and in an Atlantic bottlenose dolphin (Schaefer et al. 2009). There has been one report of C. psittaci in an aborted SSL fetal lung by Spraker \& Bradley (1996), and Schaefer et al. (2009) suggested that shedding by birds may be the explanation for C. psittaci exposure in dolphins.
The genus Morbillivirus includes phocine distemper virus (PDV), canine distemper virus (CDV), cetacean morbillivirus (CeMV), measles virus, peste-des-petits-ruminants virus and rinderpest virus. Transmission is thought to occur through direct contact and through ocular, oral or respiratory fluids (Williams 2001, Appel et al. 1981). Infection can cause severe pneumonia associated with necrosis of the bronchial and bronchiolar epithelium and neurological signs including seizures (Rowles et al. 2011, Duignan et al. 2014). PDV was first documented in 1988 causing an epidemic in European harbor seals Phoca vitulina vitulina and gray seals Halichoerus grypus (Osterhaus et al. 1990, Heide-Jørgensen et al. 1992) and again in 2002 (Jensen et al. 2002, Barrett et al. 2002, Härkönen et al. 2006). In 2006, PDV was detected in harbor seals, gray seals and hooded seals Cystophora cristata associated with an unusual mortality event off the coasts of Maine and Massachusetts (Earle et al. 2011). Goldstein et al. (2009a) detected PDV in northern sea otters Enhydra lutris kenyoni in Alaska, raising the question of exposure and infection in sympatric species in the Pacific Ocean.

The purpose of the present study was to opportunistically test archived tissue samples from aborted and intrauterine fetuses and premature and neonatal SSL pups for infection by Coxellia burnetti, Chlamydia spp., Brucella spp. and morbilliviruses by PCR, and compare results from gross necropsy and histopathologic examination and associate PCR findings with pathology. Morphometrics were used to create fetal growth curves as indicators of body condition. The focus of this paper is on pathogens that have the potential to cause reproductive failure in mammals, with SSLs as the species of interest.

\section{MATERIALS AND METHODS}

\subsection{Necropsy and sample collection}

SSL perinatal carcasses $(n=19)$ were opportunistically collected by the Alaska Marine Mammal Stranding Network, the National Marine Fisheries Service Marine Mammal Laboratory and the Alaska Department of Fish \& Game from 2002 to 2015 (Fig. 1). Necropsies were conducted by board-certified veterinary pathologists, veterinarians or trained biologists using protocols developed in Geraci \& Lounsbury (2005). Data collected included month and year, age, sex, location, region and morphometrics (Table 1). Standard length (SL), curvilinear length (CL), axillary girth (AG) and weight measurements were taken following guide- 


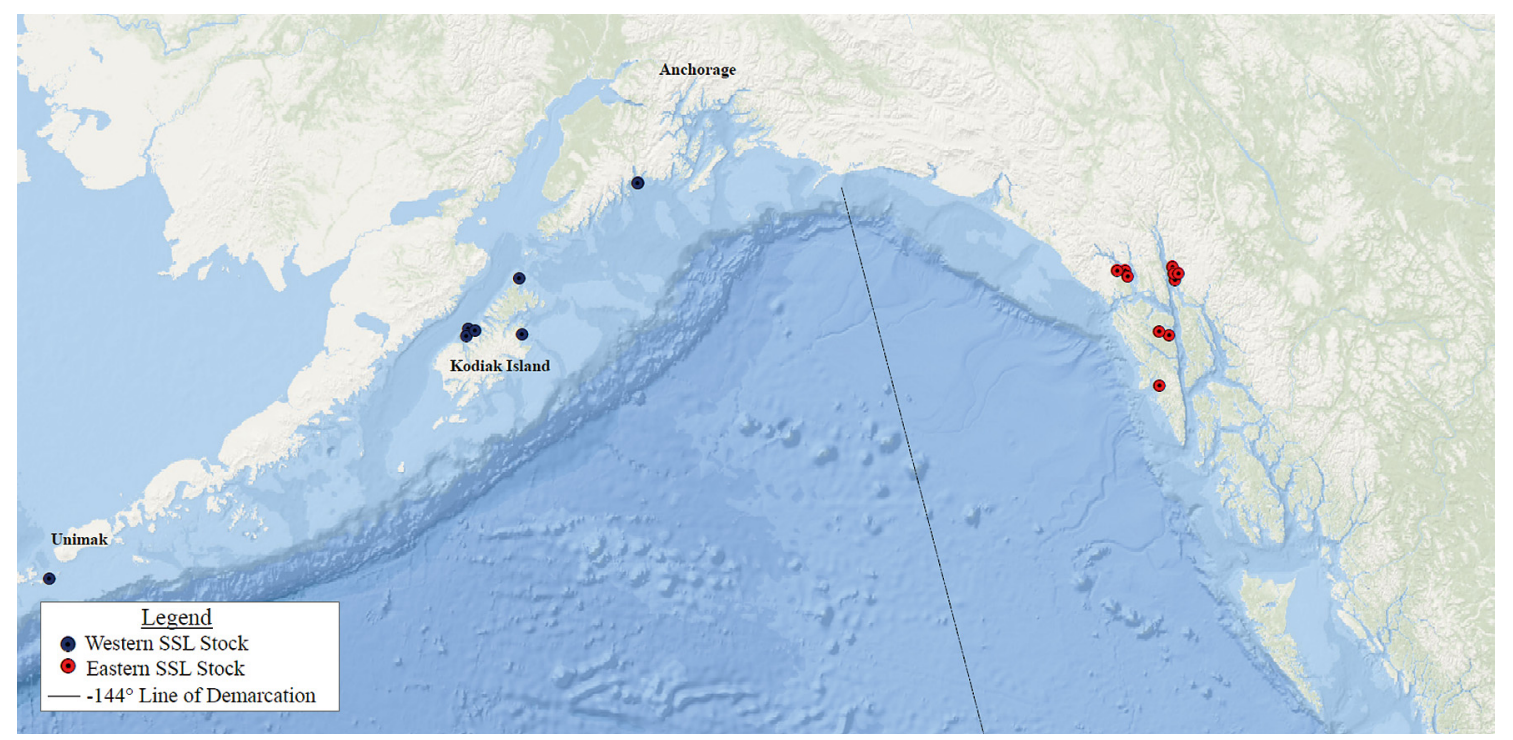

Fig. 1. Locations of sampling of aborted and intrauterine Steller sea lion (SSL) fetuses and premature and neonatal pups.

lines by Geraci \& Lounsbury (2005). Carcass condition codes were assigned to all cases at the time the necropsy was conducted and include: fresh dead $=2$, mild autolysis $=2.5$, moderate (decomposed but organs recognizable) $=3$, poor $=4$ (organs not recognizable, carcass intact), mummified or skeletonized $=5$ (Geraci \& Lounsbury 2005, Esquible \& Atkinson 2019). Age classifications were obtained from gross necropsy reports and included aborted fetus, intrauterine fetus, premature pup and neonatal pup. If the lungs did not float in formalin, the age was defined as an aborted fetus; if the lungs did float and the animal was born outside normal pupping season, the age was defined as a premature pup. The gross findings of atelectasis were confirmed by histopathology (Colegrove et al. 2016). Neonatal pups were identified by having fresh umbilical stumps. Intrauterine fetuses were collected from a mother harvested by a subsistence hunter

Table 1. Summary of Steller sea lion (SSL) aborted and intrauterine (IU) fetuses, premature pups and neonatal pups from harvested or stranded adult females by month and year, age class, sex, location, stock, weight, standard length (SL), curvilinear length (CL), axillary girth, body condition and carcass classification (2: fresh dead; 2.5: mild autolysis; 3: moderate; 4: poor; 5: mummified or skeletonized)

\begin{tabular}{|lcccccccccc|}
\hline $\begin{array}{l}\text { SSL } \\
\text { ID }\end{array}$ & Month & Year & $\begin{array}{c}\text { Age } \\
\text { classification }\end{array}$ & Sex & Stock & $\begin{array}{c}\text { Weight } \\
(\mathrm{kg})\end{array}$ & $\begin{array}{c}\text { SL } \\
(\mathrm{cm})\end{array}$ & $\begin{array}{c}\text { CL } \\
(\mathrm{cm})\end{array}$ & $\begin{array}{c}\text { Axillary } \\
\text { girth (cm) }\end{array}$ & $\begin{array}{c}\text { Carcass } \\
\text { classification }\end{array}$ \\
\hline 1 & Mar & 2002 & Premature & Female & West & 5 & 61 & 68 & 38 & 2 \\
2 & Mar & 2004 & Premature & Male & East & 7 & 74 & 77.3 & 40.9 & 2 \\
3 & Apr & 2004 & Aborted & Male & East & 20 & 100 & 103.5 & 56.5 & 2 \\
4 & Mar & 2004 & Premature & Female & East & 20 & 71.6 & 81.6 & 44 & 3 \\
5 & Mar & 2005 & Premature & Male & East & 6.3 & 65 & 71.5 & 41.5 & 2.5 \\
6 & Mar & 2005 & IU fetus & Female & Unknown & 8.1 & 70.4 & 76.4 & 43.4 & 2 \\
7 & Mar & 2006 & Aborted & Female & East & 5.5 & 64 & 67 & 45 & 2 \\
8 & Apr & 2006 & Aborted & Female & East & 9.5 & 81.6 & 86 & 64 & 2.5 \\
9 & Apr & 2008 & Premature & Male & East & 15 & 86 & 93.5 & 54.5 & 38.7 \\
10 & Apr & 2012 & Premature & Male & West & 7.3 & 77.2 & 38.7 & 2 \\
11 & Apr & 2012 & Aborted & Male & West & 9.5 & 81.5 & 87.5 & Unknown \\
12 & Apr & 2012 & Premature & Female & West & 6.8 & 71 & 77.5 & 39.9 & 3 \\
13 & Mar & 2013 & Premature & Female & West & 6.4 & 63.2 & 68.4 & 40.6 & 38 \\
14 & Mar & 2013 & IU fetus & Female & East & 4.5 & 54.5 & 61 & 3 \\
15 & May & 2013 & Neonate & Male & West & 17.4 & 101 & 109 & 56.5 & 2 \\
16 & May & 2013 & Premature & Male & West & 15.4 & 92 & 95.2 & Unknown \\
17 & Apr & 2014 & Aborted & Male & East & 8.6 & 73 & 77 & 36.5 & 2 \\
18 & Feb & 2015 & Aborted & Female & West & Unk & 52 & 58 & 29.7 & 2 \\
19 & Jul & 2015 & Neonate & Female & East & 13 & 94.2 & 100 & 46.3 & 3 \\
\end{tabular}


(SSL6) and a dead stranded adult female (SSL14). Lung, placentas, skin lesions and other samples were collected and stored at -40 or $-80^{\circ} \mathrm{C}$. A small number of samples were collected into RNAlater $(n=23)$. Tissues were fixed in $10 \%$ buffered formalin and later embedded in paraffin and sectioned at 4-5 $\mu \mathrm{m}$ at Histology Consultation Services (Everson, WA) for histopathologic examination (Hutchinson et al. 2015).

\subsection{Fetal growth}

Fetal growth curves were used as an assessment of the body condition and nutritional status of the animal. Von Bertalanffy growth curves (von Bertalanffy $1957)$ were used to estimate fetal $(n=17)$ and neonatal weight $(\mathrm{n}=2 ; \mathrm{kg}), \mathrm{CL}(\mathrm{cm})$ and SL $(\mathrm{cm})$ as a function of month including all data with the exception of one outlying case: SSL19, one of the neonatal cases. This was removed because weight was measured after tissue samples were collected at the time of necropsy. Growth curves were estimated using the following equation:

$$
L_{t}\left(\text { or } W_{t}\right)=L^{\infty}\left(\text { or } W^{\infty}\right)\left[1-\mathrm{e}^{-K\left(t-t_{0}\right)}\right]
$$

where $L_{t}$ and $W_{t}$ describe the asymptotic size (CL, SL) or weight in the month the carcass was observed $(t)$, and $t_{0}$ is the $x$-axis intercept, or the theoretical time when either length or weight is zero. $K$ is a metabolic coefficient. The relationship between weight and length (CL and SL) was estimated by the power function equation:

$$
W=a L^{b}
$$

where $a$ is the scaling factor and $b$ determines the function's rates of growth or decay. Model parameter estimates are found in Table 2.

Table 2. Growth model and corresponding parameter estimates $( \pm \mathrm{SE})$ for $L^{\infty}$, $W^{\infty}, t_{0}$ and $K$ representing the length [curvilinear length (CL); standard length (SL)] and weight of fetal and neonatal carcasses by time, $t$, and the power function equation parameter estimates for $a$ and $b$, in which weight is a func-

\begin{tabular}{|c|c|c|c|c|}
\hline Model & Equation & 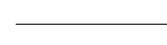 & - Parameters - & \\
\hline \multirow[t]{2}{*}{ von Bertalanffy } & $\begin{array}{c}\boldsymbol{L}_{t}=\boldsymbol{L}^{\infty}\left[\mathbf{1}-\boldsymbol{e}^{-\boldsymbol{K}\left(\boldsymbol{t}-\boldsymbol{t}_{0}\right)}\right] \\
\mathrm{CL}(\mathrm{cm}) \\
\mathrm{SL}(\mathrm{cm})\end{array}$ & $\begin{array}{c}\boldsymbol{L}^{\infty} \\
127 \pm 70.1 \\
110 \pm 18.3\end{array}$ & $\begin{array}{r}\boldsymbol{t}_{\mathbf{0}} \\
-0.31 \pm 0.38 \\
0.39 \pm 0.22\end{array}$ & $\begin{array}{c}\boldsymbol{K} \\
0.24 \pm 2.55 \\
0.61 \pm 0.75\end{array}$ \\
\hline & $W_{t}=W^{\infty}\left[1-e^{-K\left(t-t_{0}\right)}\right]$ & $\begin{array}{c}\boldsymbol{W}^{\infty} \\
15.5 \pm 3.96\end{array}$ & $\begin{array}{c}\boldsymbol{t}_{\mathbf{0}} \\
2.43 \pm 0.41\end{array}$ & $\begin{array}{c}\boldsymbol{K} \\
0.86 \pm 0.75\end{array}$ \\
\hline Power function & $\begin{array}{l}\boldsymbol{W}=\boldsymbol{a} \boldsymbol{L}^{\boldsymbol{b}} \\
\mathrm{CL}(\mathrm{cm}) \\
\mathrm{SL}(\mathrm{cm})\end{array}$ & $\begin{array}{c}\boldsymbol{a} \\
2.2 \times 10^{-4} \\
1.2 \times 10^{-4}\end{array}$ & $\begin{array}{c}\boldsymbol{b} \\
2.43 \pm 0.32 \\
2.59 \pm 0.22\end{array}$ & \\
\hline
\end{tabular}
tion of length

\subsection{Sample analysis}

Nineteen fetal lung tissues, 2 skin lesions and 1 placenta were sent to the Colorado State University Veterinary Diagnostic Laboratories to detect the presence of $C$. burnetii, Brucella spp. and all members in the genus Chlamydia. DNA was extracted using the QIAamp DNA Mini Kit (Qiagen) and $C$. burnetti DNA was detected by real-time PCR targeting fragments of the IS1111 and COM1 gene regions (Kersh et al. 2010). Brucella spp. DNA was detected by real-time PCR as described by Hinić et al. (2008) targeting a region of the IS711 gene and by a Brucella assay targeting 3 genomic regions (BRU 1, BRU 2 and BRU 3) developed by the Centers for Disease Control and Prevention (CDC). A sample was considered to be positive if the cycle threshold $\left(C_{\mathrm{t}}\right)$ value was below or equal to 40 (Duncan et al. 2014). Suspect samples were positive on 1 of 3 targets on the CDC Brucella assay and a high $C_{\mathrm{t}}$ value on the IS711 protocol. Samples that tested positive using the IS711 Brucella PCR or the CDC protocol were subsequently tested by quantitative real-time PCR (qPCR) for the detection of Brucella spp. genotype ST27 DNA (Wu et al. 2014). National Veterinary Services Laboratories attempted to culture Brucella utilizing 5 media for each sample, ranging from non-selective to highly selective, including trypticase soy with 5\% serum, trypticase soy with 5\% serum and antibiotics, trypticase soy with $5 \%$ serum, antibiotics and ethyl violet, and Ewalt's and Farrell's with 5\% serum following methods by Alton et al. (1988) with modification to homogenize tissues in the blender, and increased incubation to $15 \mathrm{~d}$ for marine mammal strains.

For morbillivirus detection, total RNA was extracted from 16 fetal lung tissues, 2 skin lesions and 1 placenta at the University of Alaska Anchorage (UAA) Bortz Laboratory and 1 bone marrow, 6 brains, 3 conjunctival swabs, 4 skin lesions, 1 liver, 2 lymph nodes, 5 lungs, 3 nasal dry swabs, 1 oral dry swab, 2 placentas, 2 rectal dry swabs, 3 normal skin, 1 spleen dry swab, 1 stomach contents, and 4 thymus at the University of California, Davis (UCD). Two skin lesion samples and 2 thymus samples were collected and stored in RNAlater (Thermo-Fisher Scientific). Types of samples tested were based on gross and histologic findings. Total RNA was extracted using TRIzol ${ }^{\mathrm{TM}}$ reagent (Invitrogen), and the RNA concentration was quantified using a 
NanoDrop ${ }^{\mathrm{TM}}$ spectrophotometer, ranging from 54.5 to $735.6 \mathrm{ng} \mathrm{ul}^{-1}$. Detection of morbilliviral RNA was performed by real-time, quantitative reverse-transcription PCR (qRT-PCR) using an iTaq SYBR Green One-Step (BioRad) assay in the UAA laboratory, with universal morbillivirus primers that detect a conserved region of the morbillivirus phosphoprotein (P) gene (Barrett et al. 1993); and hemi-nested diagnostic qRT-PCR was conducted by UCD with first-round morbillivirus-specific primers and second-round PDVspecific (5'-GTT CGC ATG CTT GGT TCC CTA TAC-3') and canine distemper-specific (5'-TAA TGG ATC CAC ACT CCG GAT CC-3') primers (T. A. Goldstein unpubl.). A plasmid encoding a PDV P-gene fragment was used as a positive control (T. A. Goldstein unpubl.). The first round of qRT-PCR was conducted with 100 ng RNA using 35 cycles, denaturation at $94^{\circ} \mathrm{C}$ for $2 \mathrm{~min}$, annealing at $56^{\circ} \mathrm{C}$ for $20 \mathrm{~s}$ and elongation at $72^{\circ} \mathrm{C}$ for $60 \mathrm{~s}$. The second round of qRT-PCR was conducted with PCR product from the first round and amplified with the same thermocycling conditions. Amplification ( $C_{\mathrm{t}}$ value) and melt curve analyses were conducted in the BioRad C1000 software to analyze primer specificity and detect positives $\left(C_{\mathrm{t}}<30\right)$ and suspect positives $\left(C_{\mathrm{t}}<35\right)$. UCD PCR products were cloned (Invitrogen TOPO TA Cloning Kit) and sequenced by Sanger sequencing for confirmation of positive PCR results.

\section{RESULTS}

Forty-two percent of SSL carcasses examined were from the western stock and 53\% were from the eastern stock (Fig. 1). Ages included $47 \%$ premature pups, 32\% aborted fetuses, 10\% intrauterine fetuses and $11 \%$ neonates (Table 1 ). The month of carcass collection varied from February to July, and $47 \%$ were male and $53 \%$ were female. Weights ranged from $4.5 \mathrm{~kg}$ (intrauterine fetus) to $20 \mathrm{~kg}$, with an mean $\pm \mathrm{SD}$ weight of $10.3 \pm 5.2 \mathrm{~kg}$, excluding one carcass due to discrepancies in weight measurements. Carcass condition varied and included $63 \%$ fresh (code 3 ; $\mathrm{n}=12), 16 \%$ mildly autolyzed $(2.5 ; \mathrm{n}=3)$ and $21 \%$ in moderate condition $(3 ; \mathrm{n}=4)$. No cases were in poor (4) or mummified/skeletonized (5) condition. The fetal growth curves were analyzed to assess the relationship between weight, SL and CL as a function of time and were estimated using the von Bertalanffy growth curves (Fig. 2A-C) and a power function equation (Fig. 2D-E) excluding SSL19. Three of the SSL are plotted below the growth curve, 2 of which have notes indicating an emaciated body condition. For SSL19, there was no relationship between axillary girth and month using the model (Table 2), and therefore these data were not included in growth curve figures.

Aborted fetuses recovered in March were haired over the dorsal midline, with more complete coats over the hips and head, and the ventrum was hairless (Fig. 3A). Evidence of dystocia or entanglement in the umbilical cord occurred in 4 cases and was characterized by distinct demarcation and patterns of congestion, edema and hemorrhage to the head or hind quarters (Fig. 3B). Seven animals had vesiculoulcerative dermatitis (Table 3, Fig. 3C), which extended to the umbilical cord in one animal (Fig. 3D). Hemorrhage of varying degree and location was present in 10 animals (Table 3, Fig. 3E). Two animals had congenital defects. SSL8 had lesions consistent with chondrodysplasia, characterized by a distorted and tortuous trachea with marked variations in the diameter of the lumen due to multiple nodular thickenings of the tracheal cartilages and similar cartilaginous nodular distortions of the lungs and rib cage (Table 3). In SSL9, the heart was partially scavenged; findings of the remainder of the heart indicated an overriding aorta with no apparent atrioventricular valves. Emaciation was evident in 2 neonates.

Histologically, placentitis was not appreciated in any of the cases in which the placenta was available for examination. SSL12 had several shallow erosions and ruptured vesicles and ulcers around the ventral pelvic area and umbilicus. Skin lesions were characterized by diffuse lymphocytic, neutrophilic and histiocytic dermal inflammatory infiltrate and marked dermal and subcutaneous edema and hemorrhage. The epithelium had patches of acanthosis (Fig. 4A) in which the epithelial cells appeared to be fused, forming a syncytium, with distinct juxtanuclear and perinuclear vacuoles, in one case containing 1-3 amphophilic to basophilic inclusion bodies (Fig. 4B). In other areas, there was distinctive rounding up and separation of the subcorneal keratinocytes, consistent with acantholytic cells (Fig. 4C). Peripheral lymph nodes had a neutrophilic drainage reaction and many lymph nodes had hemorrhage with erythrophagocytosis.

PCR results for Chlamydia and C. burnetii were negative in all tissues (Table 4). Three animals were positive and one suspect positive for Brucella spp. (Table 4). One of these animals tested positive for the Brucella spp. ST27 genotype (SSL8), but attempts to culture Brucella were unsuccessful at USDA's National Veterinary Services Laboratory. Molecular characterization by MLVA was also unsuccessful due to the presence of low amounts of DNA. The gross 

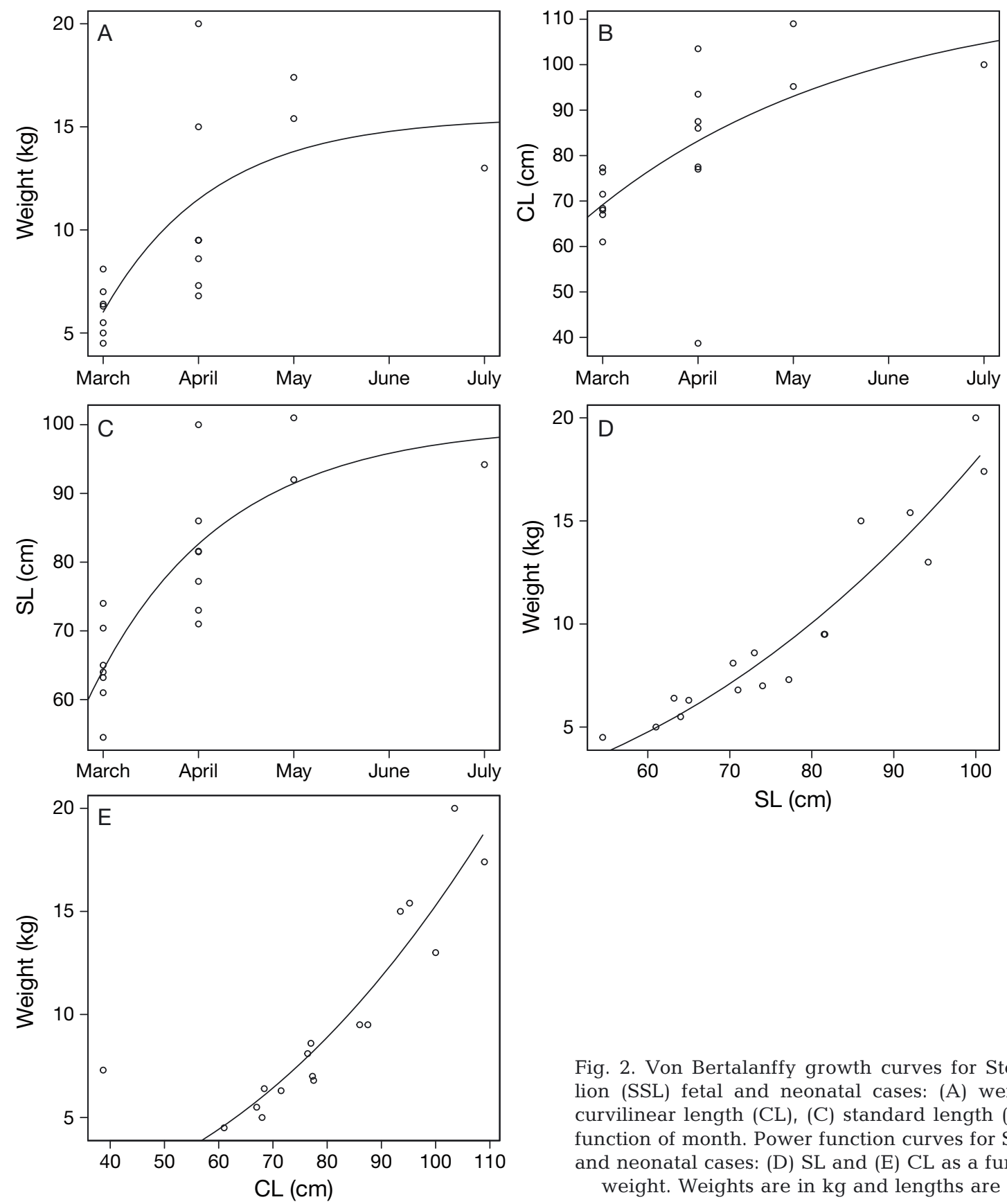

Fig. 2. Von Bertalanffy growth curves for Steller sea lion (SSL) fetal and neonatal cases: (A) weight, (B) curvilinear length (CL), (C) standard length (SL) as a function of month. Power function curves for SSL fetal and neonatal cases: (D) SL and (E) CL as a function of weight. Weights are in $\mathrm{kg}$ and lengths are in $\mathrm{cm}$

and histopathologic findings for the 3 Brucella spp. positives did not demonstrate typical findings due to Brucella infection. Infected animals had a variety of findings including a cardiac defect, dystocia and other evidence of trauma. Placentas were not available for examination.

Two animals were positive (2 skin lesions and 1 placenta; Table 4) for PDV by PCR at UCD and this was confirmed by sequencing. One of these animals also had a suspect positive result in the lung, and 2 other animals had a suspect positive result in a skin

lesion and a lung at UAA. The 3 animals positive or suspect positive for PDV in the skin had a distinctive vesiculoulcerative dermatitis (Fig. 3C,D) and myocardial hemorrhage and edema (Fig. 3E, Table 3). These animals formed part of an increase in abortions on Kodiak Island, with 4 animals presented at the same time with similar lesions. The other suspect positive lung sample tested at UAA had no gross pathology signs suggestive of disease (SSL19). The suspect positive samples at UAA were still undergoing analysis at the time of this study. 

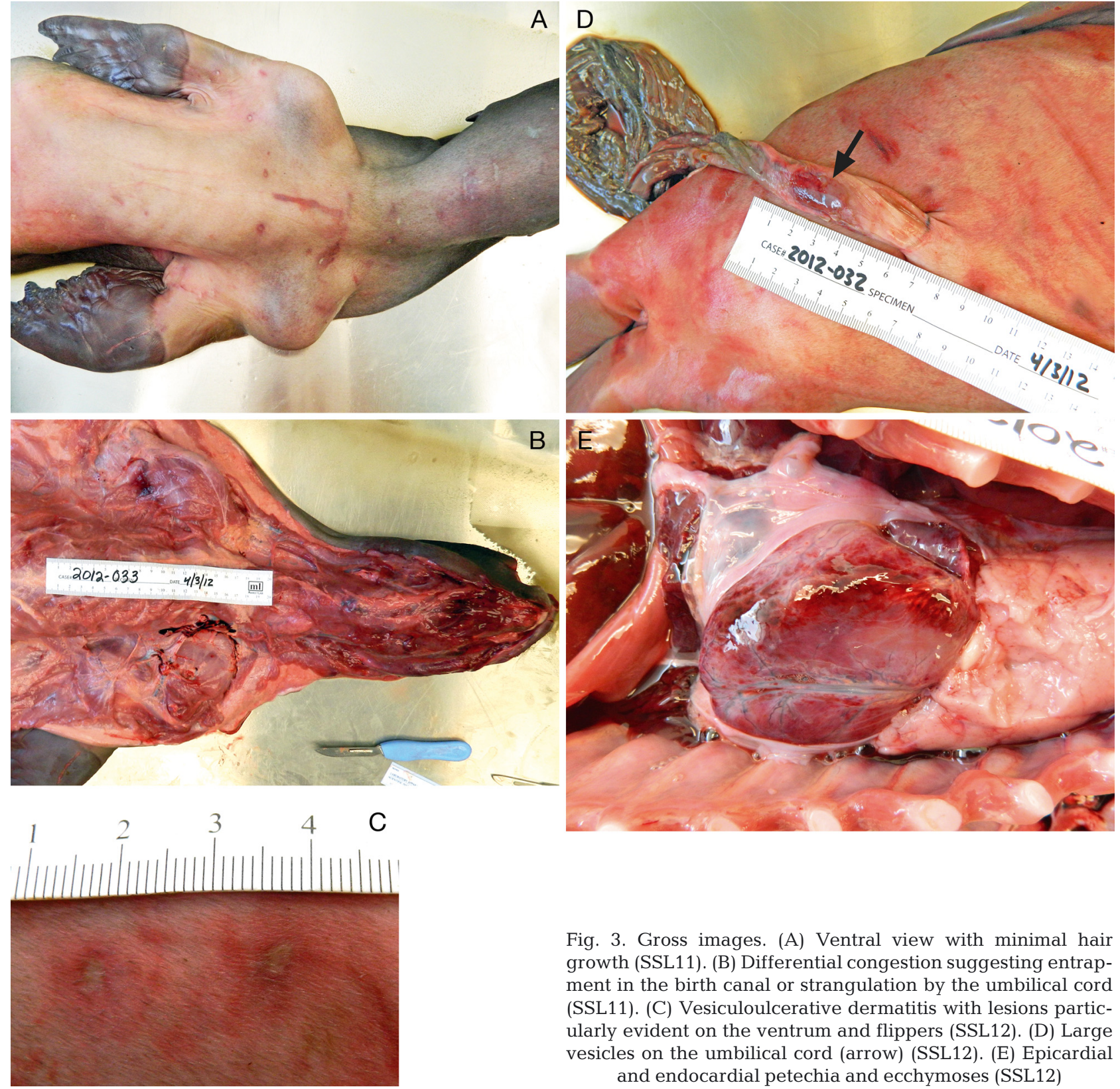

Fig. 3. Gross images. (A) Ventral view with minimal hair growth (SSL11). (B) Differential congestion suggesting entrapment in the birth canal or strangulation by the umbilical cord (SSL11). (C) Vesiculoulcerative dermatitis with lesions particularly evident on the ventrum and flippers (SSL12). (D) Large vesicles on the umbilical cord (arrow) (SSL12). (E) Epicardial and endocardial petechia and ecchymoses (SSL12)

\section{DISCUSSION}

Infectious disease agents such as Brucella spp., Coxiella burnetii and Chlamydia spp. are known to cause reproductive failure and neonatal mortality in species other than SSLs and therefore could potentially affect a population's growth trajectory (Gaydos et al. 2004, Borel et al. 2006). The present study expands upon previous research efforts in determining whether C. burnetii, Chlamydia spp., Brucella spp. and morbilliviruses contribute to SSL reproductive failure (Burek et al. 2005). The present study de-

tected Brucella spp. in 4 animals, confirming the presence of Brucella spp. in SSLs and in particular the presence of the ST27 genotype, a zoonotic strain posing potential public health concerns and the first confirmation of this genotype in Alaska. Previously, the only indication of Brucella spp. infection of SSLs was through serological surveys (Burek et al. 2005, Nymo et al. 2018). Thus far, detection of Brucella spp. in otariid seals inhabiting Alaska waters has only been in northern fur seals, and 1 case exhibited severe placentitis (Duncan et al. 2014). In our study, the 3 SSL cases that were PCR positive for Brucella 
Table 3. Summary of steller sea lion (SSL) gross necropsy and histopathology findings compared with PCR positives. PDV: phocine distemper virus; L: lung; SI: skin lesion; P: placenta

\begin{tabular}{|c|c|c|c|c|c|}
\hline $\begin{array}{l}\text { SSL } \\
\text { ID }\end{array}$ & Hemorrhage & $\begin{array}{l}\text { Evidence } \\
\text { of dystocia }\end{array}$ & $\begin{array}{l}\text { Derma- } \\
\text { titis }\end{array}$ & PCR positive & Other findings \\
\hline 1 & $\mathrm{Y}$ & $\mathrm{N}$ & $\mathrm{N}$ & Suspect Brucella (L) & Vacuolar nephropathy \\
\hline 2 & $\begin{array}{l}\text { Y epi- and } \\
\text { endocardium }\end{array}$ & $\mathrm{N}$ & $\mathrm{N}$ & & $\begin{array}{l}\text { Generalized organ congestion; pigmentary, hepatopathy, } \\
\text { pneumonia, focal, pyogranulomatous, associated with } \\
\text { hair shaft, degenerative myopathy }\end{array}$ \\
\hline 3 & $\mathrm{~N}$ & $\mathrm{Y}$ & $\mathrm{N}$ & & $\begin{array}{l}\text { Regional subcutaneous edema to the head and pulmonary } \\
\text { edema; trauma with liver fracture }\end{array}$ \\
\hline 4 & $\mathrm{Y}$ & $\mathrm{N} ?$ & $\mathrm{~N}$ & Brucella (L) & Edema involving neck, head chest and abdomen \\
\hline 5 & $\mathrm{Y}$ & $\mathrm{Y}$ & $\mathrm{N}$ & & $\begin{array}{l}\text { Antemortem trauma to head, fractured liver and puncture } \\
\text { wounds to body; generalized organ congestion; muscle } \\
\text { degeneration; epicarditis, mixed, pulmonary edema, } \\
\text { congestion etc. }\end{array}$ \\
\hline 6 & $\mathrm{~N}$ & $\mathrm{~N}$ & $\mathrm{~N}$ & & $\begin{array}{l}\text { Normal fetus collected during subsistence hunt; minor } \\
\text { focal trauma to head and thorax; extracted from mother }\end{array}$ \\
\hline 7 & $\mathrm{~N}$ & $\mathrm{~N}$ & $\mathrm{Y}$ & & Severe chondrodysplasia (congenital defect) \\
\hline 8 & $\mathrm{~N}$ & $\mathrm{~N}$ & $\mathrm{~N}$ & Brucella (L) & Cardiac congenital defect \\
\hline 9 & $\mathrm{Y}$ & $\mathrm{Y}$ & $\mathrm{N}$ & & Congestion and edema \\
\hline 10 & $\mathrm{Y}$ & $\mathrm{N}$ & $\mathrm{Y}$ & PDV (SI) & $\begin{array}{l}\text { Mild suppurative lymphadenitis of peripheral lymph } \\
\text { nodes; poor body condition }\end{array}$ \\
\hline 11 & Y endocardium & $\mathrm{Y}$ & $\mathrm{Y}$ & Suspect PDV (SI) & $\begin{array}{l}\text { Several shallow erosions/ruptured vesicles/ulcers around } \\
\text { the ventral pelvic area and umbilicus; emaciated }\end{array}$ \\
\hline 12 & $\mathrm{Y}$ & $\mathrm{N}$ & $\mathrm{Y}$ & $\mathrm{PDV}(\mathrm{SL}, \mathrm{P})$ & $\begin{array}{l}\text { Myocardial edema; stomatitis; scattered ruptured vesicles } \\
\text { on its abdomen, neck and hind flippers }\end{array}$ \\
\hline 13 & $\mathrm{~N}$ & $\mathrm{~N}$ & $\mathrm{Y}$ & & $\begin{array}{l}\text { Marked meconium staining (fetal distress); vesicular } \\
\text { lesions on the hind flippers; mild lymphocytic epicarditis } \\
\text { and endocarditis }\end{array}$ \\
\hline 14 & $\mathrm{Y}$ & $\mathrm{N}$ & $\mathrm{Y}$ & & Intrauterine fetus of mother that died of unknown causes \\
\hline 15 & $\mathrm{~N}$ & $\mathrm{~N}$ & $\mathrm{Y}$ & & $\begin{array}{l}\text { Suspect death due to inanition; poor body condition; mild } \\
\text { pulmonary congestion and edema }\end{array}$ \\
\hline 16 & $\mathrm{~N}$ & $\mathrm{~N}$ & $\mathrm{Y}$ & & $\begin{array}{l}\text { Minor trauma; mild erosions in the mouth and vesicular } \\
\text { skin lesions on the umbilicus }\end{array}$ \\
\hline 17 & $\mathrm{~N}$ & $\mathrm{~N}$ & $\mathrm{~N}$ & & Head trauma \\
\hline 18 & $\mathrm{Y}$ & $\mathrm{N}$ & $\mathrm{N}$ & & Not applicable \\
\hline 19 & $\mathrm{~N}$ & $\mathrm{~N}$ & $\mathrm{~N}$ & Suspect PDV (L) & $\begin{array}{l}\text { Emaciated and likely asphyxiated; possibly an in utero } \\
\text { infection occurred or poor nutritional state of the mother; } \\
\text { omphalitis }\end{array}$ \\
\hline
\end{tabular}

spp. in lung tissue did not demonstrate pneumonia, as can be seen in other species in some cases of abortion due to Brucella. Thus, similar to Godfroid (2002), our findings did not suggest an association of lesions with infection. However, lack of placental tissues hinders a complete analysis, as Brucella spp. primarily cause abortion through placentitis. High real-time $C_{\mathrm{t}}$ values detected in this study could indicate either low levels of bacterial DNA, sample contamination or false positives. The ST27 PCR was performed at another location approximately $1.5 \mathrm{yr}$ after the original PCR analyses, and samples with an initially high $C_{\mathrm{t}}$ value can be difficult to repeat given the long storage interval between collection, testing and sample shipping. Examination and testing of placentas would have been optimal to confirm whether Brucella contributed to reproductive failure in these cases. How- ever, placenta is not often available as it is consumed rapidly by scavengers. In future, more effort should be made to collect and test placentas for Brucella to determine the significance of these findings.

In the present study, we used a qRT-PCR assay, which detected PDV in 2 premature pups, 1 aborted pup and 1 neonate, with 2 cases confirmed by sequencing. The detection of PDV in the placenta and skin by PCR was associated with pathology suggestive of PDV infection, given the presence of mononuclear inflammation, syncytia and inclusion bodies (Duignan et al. 2014). Three of these cases occurred within a short period of time and demonstrated similar pathology in 4 aborted or premature animals on Kodiak, which is habitat for part of the endangered western population. The close time frame of these cases strongly supports an infectious or toxic cause 


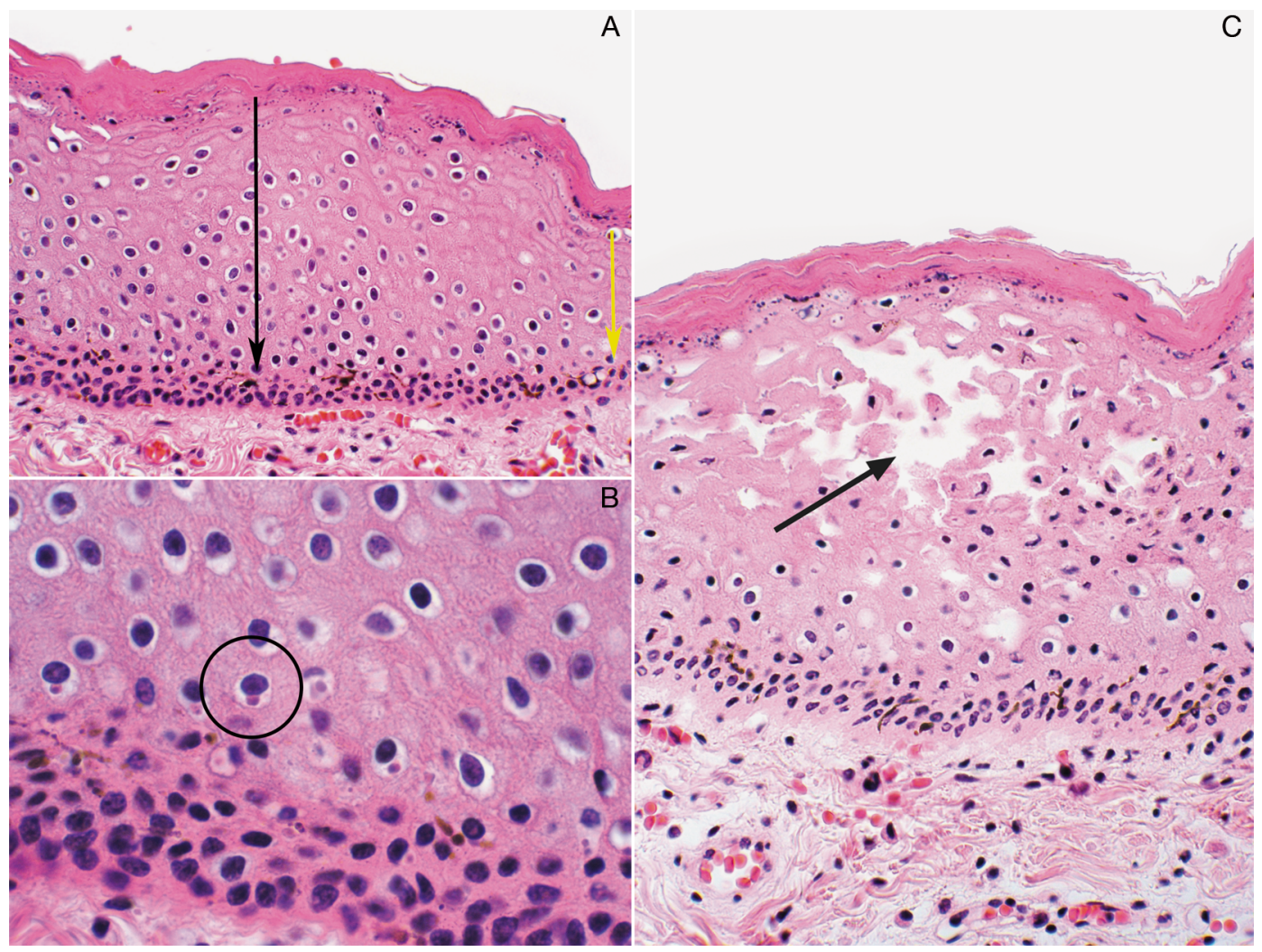

Fig. 4. Hind flipper from SSL13. (A) The epithelium has patches of thickened epithelium due to increased thickness of the stratum spinosum (black arrow) versus the more normal thickness (yellow arrow) (40x). (B) Epithelial cells fused into a syncytium, with distinct juxtanuclear and perinuclear vacuoles, often containing 1-3 amphophilic to basophilic inclusion bodies (circle) 100x. (C) Areas with distinctive rounding and separation of the subcorneal keratinocytes consistent with acantholysis (arrow) 40x

for the premature deliveries and abortions. PDV has been associated with skin lesions in marine mammals previously, and morbilliviral dermatitis was first documented in a hooded seal Cystophora cristata (Lipscomb et al. 2001). Goldstein et al. (2009a) detected a PDV fragment identical to the isolate from the 2002 European harbor seal outbreak in 8 live and 3 dead sea otters from the eastern Aleutian Islands and Kodiak Archipelago; however, no epizootics attributed to morbillivirus have occurred in the Pacific Northwest. Gross necropsy findings indicate the vesiculoulcerative dermatitis observed in the PDVinfected SSL was a different presentation than has been described previously for morbillivirus-associated disease; however, the confirmed detection of PDV in lesions and placenta and not in other tested tissues suggest a causative role. Our findings suggest that vertical transmission of PDV may have occurred in SSLs, as has been reported for morbillivirus infections in other species. Cetacean morbilliviruses, for example, can jump hosts to multiple cetacean and pinniped species, and may be transmitted vertically (Jo et al. 2018). It is still unclear whether PDV caused abortion or whether it was secondary to systemic infection, as indicated in other studies (e.g. Duignan et al. 2014). Thus, an understanding of the presence and pathogenicity of PDV, and potentially other morbillivirus infections in the Pacific Northwest and Alaska, is needed to better understand the risk to SSLs and sympatric species, considering our current results suggest that PDV may have had a role in reproductive failure in these SSL cases.

Disease is only one contributing factor to spontaneous abortion and premature parturition in SSLs. The presence of congenital defects was documented in 2 cases and was likely the cause of abortion. Congenital disorders and genetic defects have rarely been reported in other marine mammal species, but include multiple congenital defects in elephant seals (including cardiac defects; Trupkiewicz et al. 1997) and cardiac defects associated with abortion in an Atlantic bottlenose dolphin (Powell et al. 2009). Contaminants and harmful algal bloom exposure may also play a role (DeLong et al. 1973, Brodie et al. 2006), but were beyond the scope of the present study. It is also important to recognize abortion as a potential 
Table 4. Steller sea lion (SSL) ID, number of samples tested for Coxiella burnetii, Brucella spp., Chlamydia spp. and phocine distemper virus (PDV), and test results. Coxiella burnetti, Brucella spp. and Chlamydia spp. were tested at Colorado State University, and PDV at University of Alaska Anchorage or University of California, Davis. Note that SSL numbers marked with an asterisk were in moderate carcass classification, potentially affecting the microbiological results. BM: bone marrow; Br: brain; CS: conjunctival swab; L: lung; Li: liver; LN: lymph node; NS: nasal swab; P: placenta; RS: rectal swab; S: skin; SC: stomach contents; SI: skin lesion; SP: spleen; T: thymus

\begin{tabular}{|c|c|c|c|c|c|}
\hline SSL ID & Samples tested & Coxiella burnetii & Brucella spp. & Chlamydia & PDV \\
\hline 1 & $\mathrm{~L}$ & Negative (L) & Suspect positive (L) & Negative (L) & Negative $\left(\mathrm{L}^{\mathrm{a}}\right)$ \\
\hline 2 & $\mathrm{~L}$ & Negative (L) & Negative (L) & Negative (L) & Negative $\left(L^{a, b}\right)$ \\
\hline 3 & $\mathrm{~L}$ & Negative (L) & Negative (L) & Negative (L) & Negative $\left(L^{a}\right)$ \\
\hline $4^{*}$ & L & Negative (L) & Positive (L) & Negative (L) & Negative $\left(\mathrm{L}^{\mathrm{a}}\right)$ \\
\hline 5 & $\mathrm{~L}, \mathrm{Br}, \mathrm{P}$ & Negative (P) & Positive (L) & Negative (L) & Negative $\left(\mathrm{BR}^{\mathrm{b}}, \mathrm{L}^{\mathrm{a}}\right)$ \\
\hline 6 & L & Negative (L) & Negative (L) & Negative (L) & Negative $\left(L^{\mathrm{a}}\right)$ \\
\hline 7 & $\mathrm{~L}, \mathrm{NS}, \mathrm{P}$ & Negative $(\mathrm{L}, \mathrm{P})$ & Negative (L) & Negative (L) & Negative $\left(L^{a}, N S^{b}\right)$ \\
\hline 8 & $\mathrm{~L}$ & Negative (L) & Positive (L) & Negative (L) & Negative $\left(L^{\mathrm{a}}\right)$ \\
\hline 9 & $\mathrm{~L}, \mathrm{Br}$ & Negative (L) & Negative (L) & Negative (L) & Negative $\left(\mathrm{Br}^{\mathrm{b}}, \mathrm{L}^{\mathrm{a}, \mathrm{b}}\right)$ \\
\hline $10^{*}$ & $\mathrm{Br}, \mathrm{L}, \mathrm{SI}, \mathrm{T}$ & Negative (L) & Negative (L) & Negative (L) & $\begin{array}{c}\text { Positive }\left(\mathrm{SI}^{\mathrm{b}}\right) ; \\
\text { negative }\left(\mathrm{Br}^{\mathrm{b}}, \mathrm{L}^{\mathrm{a}}, \mathrm{T}^{\mathrm{b}}\right)\end{array}$ \\
\hline $11^{*}$ & $\begin{array}{l}\mathrm{Br}, \mathrm{CS}, \mathrm{L}, \mathrm{Li}, \mathrm{LN} \text {, } \\
\text { RS, SC, T }\end{array}$ & Negative (L, SI) & Negative (L, SI) & Negative (L, SI) & $\begin{array}{c}\text { Suspect positive }\left(\mathrm{SI}^{\mathrm{a}}\right)_{i} \\
\text { negative }\left(\mathrm{Br}^{\mathrm{b}}, \mathrm{CS}^{\mathrm{b}}, \mathrm{LN}^{\mathrm{b}},\right. \\
\left.\mathrm{Li}^{\mathrm{b}}, \mathrm{T}^{\mathrm{b}}, \mathrm{L}^{\mathrm{a}}\right)\end{array}$ \\
\hline 12 & $\begin{array}{l}\text { BM, Br, CS, L, NS, } \\
\text { P, RS, SI, SP, T }\end{array}$ & Negative $(L, P)$ & Negative (L) & Negative (L) & $\begin{array}{c}\text { Positive }^{\mathrm{b}}(\mathrm{SI}, \mathrm{P}) ; \\
\text { positive }^{\mathrm{a}}(\mathrm{L}) ; \text { negative }^{\mathrm{b}} \\
(\mathrm{BM}, \mathrm{Br}, \mathrm{CS}, \mathrm{NS}, \mathrm{RS}, \mathrm{SP}, \mathrm{T})\end{array}$ \\
\hline 13 & LN, L, NS, S, SC, T & Negative (L, SC) & Negative (L) & Negative (L) & Negative (L, LN, NS, S, T) \\
\hline 14 & CS, L, P, SI & Negative $(\mathrm{L}, \mathrm{P})$ & Negative $(\mathrm{L}, \mathrm{P})$ & Negative $(\mathrm{L}, \mathrm{P})$ & Negative (CS, P, SI) \\
\hline 15 & $\mathrm{Br}, \mathrm{L}, \mathrm{S}$ & Negative (L) & Negative (L) & Negative (L) & Negative (Br, L, S) \\
\hline 16 & L & Negative (L, SI) & Negative (L, SI) & Negative (L, SI) & Negative (L, SI) \\
\hline 17 & $\mathrm{~L}$ & Negative (L) & Negative (L) & Negative (L) & Negative (L) \\
\hline $18^{*}$ & $\mathrm{~L}$ & Negative (L) & Negative (L) & Negative (L) & Negative (L) \\
\hline 19 & $\mathrm{~L}$ & Negative (L) & Negative (L) & Negative (L) & $\begin{array}{l}\text { Suspect positive }^{\mathrm{a}}(\mathrm{L}) ; \\
\text { negative }(\mathrm{L})\end{array}$ \\
\hline
\end{tabular}

reproductive strategy of otariids during periods of nutritional stress in order to increase their reproductive performance (Testa 1987, Pitcher et al. 1998). Considering this, it should also be recognized that pinnipeds evolved to practice embryonic diapause, which would serve the same purpose acting earlier in gestation with less energetic costs. Breeding in otariid species has been described as 'energetically expensive' (Costa 1993), and as a result, SSLs may have evolved multiple lactation and gestational mating strategies to allow for optimal reproductive success (Atkinson 1997). Despite our small sample size, this study found 2 cases that were emaciated (SSL11 and SSL19; Table 3), with no other findings suggestive of nutritional stress. Both had morphometrics that fell below the growth curves that were created using the von Bertalanffy equations, confirming the utility of this analysis for assessing body condition in this age class.

Additional data compiled in this study provide valuable insights into time, sex, location and morphometrics of aborted and premature fetuses and the neonatal deaths. The time frame in which the fetal and neonatal carcasses were collected ranged from February to July. The weight and length data fit the von Bertalanffy growth curves reasonably well, approaching an asymptote in May (Fig. 2). The relationship between fetal length and weight was also estimated by the power function equation, in which weight increased as SL and CL increased by a factor of $b$ (Fig. 3). Although we were unable to compare our growth curves to other SSL fetal growth curves, we were able to compare the weight to other pinniped research findings. The neonatal pups SSL15 and SSL19 were included in the present study because they were not suspected to have lived longer than 1-5 $d$ and were fairly close in weight, SL, CL and AG to other cases. Additionally, diseases that cause late-term abortion are often associated with weak neonatal animals. A study conducted in southeast Alaska, the Gulf of Alaska and the Aleutian Islands found the average weight of neonatal pups at $1-5 \mathrm{~d}$ old to be $22.4 \pm 2.36 \mathrm{~kg}$ for males and $18.7 \pm$ $2.08 \mathrm{~kg}$ for females, which is higher than the weight 
of the 2 neonates in the present study (Brandon et al. 2005). This is expected, considering the body condition of the neonates in this study was poor (SSL15) and emaciated (SSL19; Table 1) and likely contributed to mortality. The male premature pup found in May weighed $15.4 \mathrm{~kg}$, whereas the premature female pup and male aborted fetus found in March and April weighed $20 \mathrm{~kg}$, which seems rather high in comparison to the average neonatal pup weight illustrated by Brandon et al. (2005) in May and June. Further work should be conducted to determine SSL fetal growth, like that performed for other pinniped species (Hutchinson et al. 2016).

In conclusion, we attempted to understand whether C. burnetii, Brucella spp., Chlamydia and morbilliviruses play a role in spontaneous abortion, premature pup and neonatal deaths in SSL in the North Pacific. Though findings were negative for $C$. burnetii and Chlamydia, marine Brucella and PDV were detected, yielding detection of a zoonotic disease agent (ST27 Brucella strain) and novel insight into pathology that may be associated with morbillivirus infection. We fully recognize that the sample size and geographic range covered in this study are insufficient to make conclusions about the effect these pathogens play on reproductive failure at the population level, but results suggest they do affect survival of some individuals. In order to make broader conclusions over a larger geographic range, stranding efforts and disease surveillance monitoring efforts, particularly for Brucella and PDV, should be improved to support more comprehensive monitoring in remote, rural areas around Alaska.

Acknowledgements. We thank the Alaska Department of Fish \& Game (ADF\&G) staff Mandy Keogh, Lauri Jemison and Michael Rehberg for their assistance in obtaining reports and archived tissue samples and providing financial support for further Brucella testing; Brett Smith at the University of California Davis for PCR analyses and assistance with protocols; Jacques Godfroid with University of Tromsø - the Arctic University of Norway for providing his expertise and guidance with the Brucella analyses; Ben Staton, for guidance and assistance with statistical analyses; Christina Weller at the CSU Veterinary Diagnostic Laboratory for technical assistance; Christine Quance with National Veterinary Services Laboratories for conducting additional Brucella analyses; Thijs Kuiken at Erasmus Medical Center for helpful discussions; Sherry Tamone and Keith Cox for ongoing support and guidance; and our undergraduate mentee Cole Deal, who assisted with organization of the data and construction of the maps. Rasmuson Research Fisheries Center and NIAID CEIRS (contract HHSN272201400008C) provided support for this project. Cases were collected under the Marine Mammal Health and Stranding Program (MMHSP) permits 932-1905/MA-009526 and 18786; ADF\&G permits 358-1564, 358-1769 and 358-1888; and Marine
Mammal Laboratory permit 782-1532. Some of the samples were collected through the use of John H. Prescott Marine Mammal Rescue Assistance Grant no. NA12NMF4390162.

\section{LITERATURE CITED}

Aguirre AA, Keefer TK, Reif JS, Kashinsky L, Yochem PK, Saliki JT (2007) Infectious disease monitoring of the endangered Hawaiian monk seal. J Wildl Dis 43:229-241

Alton GG, Hones LM, Angus RD, Verger JM (1988) Techniques for the brucellosis laboratory. INRA Publications, Paris

Appel MJG, Gibbs EPJ, Martin SJ, ter Meulen V, Rima BK, Stephenson JR, Taylor WP (1981) Morbillivirus diseases of animals and man. In: Kurstak E, Kurstak C (eds) Comparative diagnosis of viral disease, IV. Academic Press, New York, p 235-297

Arricau-Bouvery N, Rodolakis A (2005) Is Q Fever an emerging or re-emerging zoonosis? Vet Res 36:327-349

Atkinson S (1997) Reproductive biology of seals. Rev Reprod 2:175-194

Atkinson S, Demaster DP, Calkins DG (2008) Anthropogenic causes of the western Steller sea lion Eumetopias jubatus population declines and their threat to recovery. Mammal Rev 38:1-18

Barrett T, Visser IKG, Mamaev L, Goatley L, van Bressem MF, Osterhaus ADME (1993) Dolphin and porpoise morbilliviruses are genetically distinct from phocine distemper virus. Virology 193:1010-1012

Barrett T, Sahoo P, Jepson PD (2002) Seal distemper outbreak 2002. Microbiol Today 30:162-164

*Beeckman DSA, Vanrompay DCG (2009) Zoonotic Chlamydophila psittaci infections from a clinical perspective. Clin Microbiol Infect 15:11-17

* Borel N, Thoma R, Spaeni P, Weilenmann R and others (2006) Chlamydia-related abortions in cattle from Graubunden, Switzerland. Vet Pathol 43:702-708

Brandon EAA, Calkins DG, Loughlin TR, Davis RW (2005) Neonatal growth of Steller sea lion (Eumetopias jubatus) pups in Alaska. Fish Bull 103:246-257

Brodie EC, Gulland FMD, Greig DJ, Hunter M and others (2006) Domoic acid causes reproductive failure in California sea lions (Zalophus californianus). Mar Mamm Sci 22:700-707

Burek KA, Gulland FMD, Sheffield G, Beckmen KB and others (2005) Infectious disease and the decline of steller sea lions (Eumetopias jubatus) in Alaska, USA: insights from serologic data. J Wild Dis 41:512-524

Calkins DG, Goodwin R (1988) Investigations of the declining sea lion population in the Gulf of Alaska. Alaska Department of Fish and Game, Anchorage

Colegrove KM, Venn-Watson S, Litz J, Kinsel MJ and others (2016) Fetal distress and in utero pneumonia in perinatal dolphins during the Northern Gulf of Mexico unusual mortality event. Dis Aquat Org 119:1-16

Costa DP (1993) The relationship between reproductive and foraging energetics and the evolution of Pinnipedia. Symp Zool Soc Lond 66:293-314

*DeLong RL, Gilmartin WG, Simpson JG (1973) Premature births in California sea lions: association with high organochlorine pollutant residue levels. Science 181: 1168-1170

* Duignan PJ, Van Bressem MF, Baker JD, Barbieri M and others (2014) Phocine distemper virus: current knowledge and future directions. Viruses 6:5093-5134 
Duncan CG, Tiller R, Mathis D, Stoddard R, Kersh GJ, Dickerson B, Gelatt T (2014) Brucella placentitis and seroprevalence in northern fur seals (Callorhinus ursinus) of the Pribilof Islands, Alaska. J Vet Diagn Invest 26:507-512

Earle JAP, Melia MM, Doherty NV, Nielsen O, Cosby SL (2011) Phocine distemper virus in seals, East Coast, United States, 2006. Emerg Infect Dis 17:215-220

Esquible JA, Atkinson S (2019) Stranding trends in Steller sea lions Eumetopias jubatus 1990-2015. Endang Species Res 38:177-188

Ewalt DR, Payeur JB, Martin BM, Cummins DR, Miller WG (1994) Characteristics of a Brucella species from a bottlenose dolphin (Tursiops truncatus). J Vet Diagn Invest 6: 448-452

Ferrero RC, Fritz LW (2002) Steller sea lion research coordination: a brief history and summary of recent progress. NOAA Tech Memo NMFS-AFSC-129

Foster G, MacMillan AP, Godfroid J, Howie F and others (2002) A review of Brucella sp. infection of sea mammals with particular emphasis on isolates from Scotland. Vet Microbiol 90:563-580

Fritz L, Sweeney KS, Johnson DS, Lynn M, Gilpatrick J (2013) Aerial ship and land-based surveys of Steller sea lions (Eumetopias jubatus) in Alaska, June and July 2008-2012. NOAA Tech Memo NMFS-AFSC-251

Gaydos JK, Balcomb KC, Osborne RW, Dieurauf L (2004) Evaluating potential infectious disease threats for southern resident killer whales, Orcinus orca: a model for endangered species. Biol Conserv 117:253-262

Geraci JR, Lounsbury VJ (2005) Marine mammals ashore: a field guide for strandings, 2nd edn. National Aquarium in Baltimore, Baltimore, MD

*Godfroid J (2002) Brucellosis in wildlife. Rev Sci Tech 21: 277-286

Goldstein T, Mazet JA, Gill VA, Doroff AM, Burek KA, Hammond JA (2009a) Phocine distemper virus in northern sea otters in the Pacific Ocean, Alaska, USA. Emerg Infect Dis 15:925-927

Goldstein T, Zabka TS, DeLong RL, Wheeler EA and others (2009b) The role of domoic acid in abortion and premature parturition of California sea lions (Zalophus californianus) on San Miguel Island, California. J Wildl Dis 45: 91-108

Guzmán-Verri C, González-Barrientos R, Hernández-Mora G, Morales JA, Baquero-Calvo E, Chaves-Olarte E, Moreno E (2012) Brucella ceti and brucellosis in cetaceans. Front Cell Infect Microbiol 2:3

Härkönen T, Dietz R, Reijnders P, Teilmann J and others (2006) A review of the 1998 and 2002 phocine distemper virus epidemics in European harbour seals. Dis Aquat Org 68:115-130

* Heide-Jørgensen M, Härkönen T, Dietz R, Thompson PM (1992) Retrospective of the 1988 European seal epizootic. Dis Aquat Org 13:37-62

* Hernández-Mora G, Palacios-Alfaro JD, Gonzalez-Barrientos R (2013) Wildlife reservoirs of brucellosis: Brucella in aquatic environments. Rev Sci Tech 32:89-103

* Hinić V, Brodard I, Thomann A, Cvetnić Z, Makaya PV, Frey J, Abril C (2008) Novel identification and differentiation of Brucella melitensis, B. abortus, B. suis, B. ovis, $B$. canis, and $B$. neotomae suitable for both conventional and real-time PCR systems. J Microbiol Meth 75: $375-378$

Holmes EE, Fritz LW, York AE, Sweeney K (2007) Age-structured modeling reveals long-term declines in the natality of western Steller sea lions. Ecol Appl 17:2214-2232

* Hoover-Miller A, Dunn JL, Field CL, Blundell G, Atkinson S (2017) Seroprevalence of Brucella antibodies in harbor seals in Alaska, USA, with age, regional, and reproductive comparisons. Dis Aquat Org 126:1-12

Hutchinson E, Atkinson S, Burek Huntington K (2015) Growth and sexual maturation in male northern sea otters (Enhydra lutris kenyoni) from Gustavus, Alaska. J Mammal 96:1045-1054

*Hutchinson E, Atkinson S, Hoover-Miller A (2016) Growth and reproductive tracts from fetal adult harbor seals in the Gulf of Alaska. Mar Ecol Prog Ser 557:277-288

Jensen T, van de Bildt M, Dietz HH, Andersen TH, Hammer AS, Kuiken T, Osterhaus A (2002) Another phocine distemper outbreak in Europe. Science 297:209

Jo WK, Kruppa J, Habierski A, van de Bildt $M$ and others (2018) Evolutionary evidence for multi-host transmission of cetacean morbillivirus. Emerg Microbes Infect 7:201

Kaleta EF, Taday EM (2003) Avian host range of Chlamydophila spp. based on isolation, antigen detection and serology. Avian Pathol 32:435-461

Kauffold J, Wehrend A, Sigmarsson H (2014) Chlamydia and Chlamydophilia in bovine reproduction. Clin Theriogenology 6:251-254

Kersh GJ, Lambourn DM, Self JS, Akmajian AM and others (2010) Coxiella burnetii infection of a Steller sea lion (Eumetopias jubatus) found in Washington State. J Clin Microbiol 48:3428

* Lambourn DM, Garner M, Ewalt D, Raverty S and others (2013) Brucella pinnipedialis infections in Pacific harbor seals (Phoca vitulina richardsi) from Washington state, USA. J Wildl Dis 49:802-15

K Lapointe JM, Gulland FM, Haines DM, Barr BC, Duignan PJ (1999) Placentitis due to Coxiella burnetii in a Pacific harbor seal (Phoca vitulina). J Vet Diagn Invest 11:541-543

KLipscomb TP, Mense MG, Habecker PL, Taubenberger JK, Schoelkopf R (2001) Morbilliviral dermatitis in seals. Vet Pathol 38:724-726

* Longbottom D, Coulter LK (2003) Animal chlamydioses and zoonotic implications. J Comp Pathol 128:217-244

Loughlin TR (1998) The Steller sea lion: a declining species. Biosph Conserv 1:91-98

Loughlin TR, York AE (2000) An accounting of the sources of Steller sea lion mortality. Mar Fish Rev 62:40-45

* Maurin M, Raoult D (1999) Q fever. Clin Microbiol Rev 12: 518-553

Miller AJ, Trites AW, Maschner HDG (2005) Ocean climate changes and the Steller sea lion decline. Antarct J US 19: 54-63

* Minor C, Kersh GJ, Gelatt T, Kondas AV and others (2013) Coxiella burnetii in northern fur seals and Steller sea lions of Alaska. J Wildl Dis 49:441-446

Nymo IH, Tryland M, Godfroid J (2011) A review of Brucella infection in marine mammals, with special emphasis on Brucella pinnipedialis in hooded seal (Cystophora cristata). Vet Res 42:93

*Nymo IH, Rødven R, Beckmen K, Larsen AK, Tryland M, Quakenbush L, Godfroid J (2018) Brucella antibodies in Alaskan true seals and eared seals - two different stories. Vet Sci 5:8

Osterhaus AD, Groen J, Spijkers HE, Broeders HW and others (1990) Mass mortality in seals caused by newly discovered morbillivirus. Vet Microbiol 23:343-350

* Pitcher KW, Calkins DG (1981) Reproductive biology of Steller sea lions in the Gulf of Alaska. J Mammal 62:599-605 
Pitcher KW, Calkins DG, Pendelton GW (1998) Performance of female Steller sea lions: an energetics-based reproductive strategy? Can J Zool 76:2075-2083

Powell JWB, Archibald RT, Cross CA, Rotstein DS, Soop VW, McFee WE (2009) Multiple congenital cardiac abnormalities in an Atlantic bottlenose dolphin (Tursiops truncatus). J Wildl Dis 45:839-842

Rodolakis A, Salinas J, Papp J (1998) Recent advances on ovine chlamydial abortion. Vet Res 29:275-288

Rowles TK, Schwacke LS, Wells RS, Saliki JT and others (2011) Evidence of susceptibility to morbillivirus infection in cetaceans from the United States. Mar Mamm Sci 27:1-19

Sachse K, Bavoil PM, Kaltenboeck B, Stephens RS, Kuo CC, Rosselló-Móra R, Steph RS (2015) Emendation of the family Chlamydiaceae: proposal of a single genus, Chlamydia, to include all currently recognized species. Syst Appl Microbiol 38:99-103

Schaefer AM, Reif JS, Goldstein JD, Ryan CN, Fair PA, Bossart GD (2009) Serological evidence of exposure to selected viral, bacterial, and protozoal pathogens in freeranging Atlantic bottlenose dolphins (Tursiops truncatus) from the Indian River Lagoon, Florida, and Charleston, South Carolina. Aquat Mamm 35:163-170

Spraker TR, Bradley D (1996) Investigation into the health status of Steller sea lions, Eumetopias jubatus, from 1992 to 1995. In: Steller sea lion recovery investigations in Alaska, 1992-1994. Wildlife Technical Bulletin no. 13. Alaska Department of Fish and Game, Anchorage, p 88-108

Testa JW (1987) Long-term reproductive patterns and sighting bias in Weddell seals (Leptonychotes weddelli). Can J Zool 65:1091-1099

Trites AE, Donnelly CP (2003) The decline of Steller sea

Editorial responsibility: Michael Moore,

Woods Hole, Massachusetts, USA lions in Alaska: a review of the nutritional stress hypothesis. Mammal Rev 33:3-28

Trupkiewicz JG, Gulland FMD, Lowenstine LJ (1997) Congenital defects in northern elephant seals stranded along the central California coast. J Wildl Dis 33:220-225

*Van Loock M, Vanrompay D, Herrmann B, Vander Stappen J, Volckaert G, Goddeeris BM, Everett KDE (2003) Missing links in the divergence of Chlamydophila abortus from Chlamydophila psittaci. Int J Syst Evol Microbiol 53:761-770

* Vidal S, Kegler K, Greub G, Aeby S and others (2017) Neglected zoonotic agents in cattle abortion: tackling the difficult to grow bacteria. BMC Vet Res 13:373

von Bertalanffy L (1957) Quantitative laws in metabolism and growth. Q Rev Biol 32:217-231

Whatmore AM, Dawson CE, Groussaud P, Koylass MS and others (2008) Marine mammal Brucella genotype associated with zoonotic infection. Emerg Infect Dis 14: $517-518$

*Whatmore AM, Dawson C, Muchowski J, Perrett LL and others (2017) Characterisation of North American Brucella isolates from marine mammals. PLOS ONE 12: e0184758

Williams ES (2001) Canine distemper. In: William ES, Barker IK (eds) Infectious disease of wild mammals. Iowa State Press, Ames, p 50-59

*Winship AJ, Trites AW, Calkins DG (2001) Growth in body size of the Steller sea lion (Eumetopias jubatus). J Mammal 82:500-519

* Wu Q, McFee WE, Goldstein T, Tiller RV, Schwacke L (2014) Real-time PCR assays for detection of Brucella spp. and the identification of genotype ST27 in bottlenose dolphins (Tursiops truncatus). J Microbiol Methods 100:99-104

Submitted: April 10, 2019; Accepted: September 3, 2019

Proofs received from author(s): December 8, 2019 